\title{
A Sheep in Wolf's Clothing? \\ How the Illusion of Hard Law Makes Business More Responsible
}

\author{
Leitheiser, Erin
}

Document Version

Accepted author manuscript

Published in:

Proceedings of the Seventy-seven Annual Meeting of the Academy of Management

DOI:

10.5465/AMBPP.2017.253

Publication date:

2017

License

Unspecified

Citation for published version (APA):

Leitheiser, E. (2017). A Sheep in Wolf's Clothing? How the Illusion of Hard Law Makes Business More

Responsible. In G. Atinc (Ed.), Proceedings of the Seventy-seven Annual Meeting of the Academy of Management [11211] Academy of Management. Academy of Management Proceedings https://doi.org/10.5465/AMBPP.2017.253

Link to publication in CBS Research Portal

\section{General rights}

Copyright and moral rights for the publications made accessible in the public portal are retained by the authors and/or other copyright owners and it is a condition of accessing publications that users recognise and abide by the legal requirements associated with these rights.

Take down policy

If you believe that this document breaches copyright please contact us (research.lib@cbs.dk) providing details, and we will remove access to the work immediately and investigate your claim. 


\section{A Sheep in Wolf's Clothing?: How the Illusion of Hard Law Makes Business More Responsible}

\section{Erin Leitheiser}

Journal article (Accepted manuscript*)

\section{Please cite this article as:}

Leitheiser, E. (2017). A Sheep in Wolf's Clothing? How the Illusion of Hard Law Makes Business More

Responsible. In G. Atinc (Ed.), Proceedings of the Seventy-seven Annual Meeting of the Academy of Management [11211] Briar Cliff Manor, NY: Academy of Management. Academy of Management Proceedings, DOI: 10.5465/AMBPP.2017.253

DOI: 10.5465/AMBPP.2017.253

* This version of the article has been accepted for publication and undergone full peer review but has not been through the copyediting, typesetting, pagination and proofreading process, which may lead to differences between this version and the publisher's final version AKA Version of Record.

Uploaded to CBS Research Portal: February २019 


\title{
A SHEEP IN WOLF'S CLOTHING? HOW THE ILLUSION OF HARD LAW MAKES BUSINESS MORE RESPONSIBLE
}

\author{
ERIN LEITHEISER \\ Copenhagen Business School \\ Porcelænshaven 18A, 2000 Frederiksberg, Denmark
}

\begin{abstract}
While traditionally voluntary, the private governance initiative that emerged after the collapse of Rana Plaza adopted the novel tactic of using hard law to enforce its voluntary soft law agreement. This paper explores the performativity and implications of this approach, and introduces the term "illusory law" to explain the phenomenon.
\end{abstract}

\section{INTRODUCTION}

Companies are increasingly taking on heighted responsibilities for ensuring social and environmental sustainability throughout their supply chains. They have largely actualized their heightened responsibilities by engaging in partnerships and collaborations, opting in to voluntary standards and certifications, and the like. Commonly, this involves the adoption of voluntary standards - "soft law" - a trend seen with increasing frequency and complexity (Reinecke, Manning, \& von Hagen, 2012). Indeed, it is the voluntary and non-binding nature of such agreements that is often an attractive point for companies (Cashore \& Vertinsky, 2000).

When the Rana Plaza complex in Bangladesh collapsed in 2013 - leaving more than 1,100 dead and 2,500 wounded - Western businesses faced intense pressure to take on responsibilities for safety within Bangladesh garment factories by signing onto the Accord on Fire and Building Safety in Bangladesh ("the Accord"). Unprecedented in many ways, perhaps the most novel was the inclusion of a provision whereby courts in companies' home countries (hard law) could be utilized to ensure their compliance with the (soft law) agreement. Four years on, virtually all companies have fulfilled their obligations - a rather rare track record for a voluntary agreement, particularly given the large number of signatories - yet not a single court case has arisen. This then begs the question: does the use of hard law to enforce soft law lead to further business responsibilization?

This paper seeks to understand the function, performativity and implications of using hard law to enforce soft law, and in doing so aims to make three contributions. First, it sheds light upon this new and unexplored phenomenon by separating fact from fiction - legal and otherwise - when using hard law to enforce soft law. Second, it explores the perception and performativity of this approach amongst business and theorizes about its implications for the firms' role in society. Finally, it introduces the term "illusory law" as a way to explain and generalize about how this approach may be little more than a sheep in wolf's clothing.

\section{THE ACCORD ON FIRE AND BUILDING SAFETY IN BANGLADESH}

The Rana Plaza collapse happened not long after a series of other lethal accidents plagued Bangladesh's ready-made garment (RMG) factories. A voluntary initiative amongst brands to help address these types of issues had been underway for some time, yet failed to gain traction 
until after the Rana Plaza tragedy (Clean Clothes Campaign, 2013a). Then, brands and retailers came together under enormous pressure from labor and advocacy organizations to found the Accord (Reinecke \& Donaghey, 2015), a private regulatory initiative that aimed to remedy major construction, electrical and fire safety issues in the country's RMG factories. Initially, around 35 brands signed up for the Accord; this number has grown to more than 220 in under four years.

The provisions of the Accord represented a major expansion in the roles and responsibilities of the private sector; the overarching task entailed conducting detailed factory inspections, creating corrective action plans, ensuring the "financial feasibility" of upgrades, and diligently monitoring and following up to ensure remediation. In addition to taking over where government typically would have functioned, the Accord also included novel, business-changing provisions which stipulated that signatories must maintain sourcing volumes at factories, collectively cease relationships with factories that didn't comply, and to serve as a "lead brand" in a number of factories proportional to the brand's production in Bangladesh. Extraordinarily, the Accord agreement implemented a unique approach to compliance and enforcement by stipulating that the terms of the agreement could be enforced in the courts of the companies' home countries, thereby relying upon hard law enforcement of its soft law agreement. The Accord was unprecedented in scope, but more significantly, for the first time a voluntary initiative willingly and purposefully became legally-binding.

\section{HARD AND SOFT LAW}

Hard law and soft law are not binary terms, but rather, fall on a spectrum. Hard law is traditional, legally-binding obligations that typically delegate authority for implementation to the state (Abbott \& Snidal, 2000). Soft law can represent a "weakened" version of hard law, legally non-binding norms, or even "purely political arrangements in which legalization is largely absent" (Abbott \& Snidal, 2000: 422; Shelton, 2000). Soft law may have ambiguous or negotiable rules (Abbott, Keohane, Moravcsik, Slaughter, \& Snidal, 2000) and can afford nonstate actors regulatory authority (Shelton, 2000). As discussed by one legal expert, "Some scholars have distinguished hard law and soft law by stating that breach of law gives rise to legal consequences while breach of a political norm gives rise to political consequences" (Shelton, 2000: 11). Given that soft law can fall outside of the state's authority entirely, scholars have used the term to refer to a form of self-regulation that operates without a governmental power, a phenomenon also dubbed "political CSR" (Scherer \& Palazzo, 2011). Private governance initiatives rely upon soft law given their inherently voluntary nature, making the use and interaction of soft and hard law within such an initiative a significant permutation with the potential for disruptive innovation (Lawrence \& Suddaby, 2006).

\section{ACCORD AS A BREAKTHROUGH}

Virtually all accounts of the Accord heralded it as positive step forward for the RMG industry in Bangladesh, primarily due to its unprecedented scope and enforceability. A report by the International Labor Office and Global Labor University states that the Accord is "...the first initiative in the history of industrial relations where all the related stakeholder of a certain global value chain took responsibility for workers' safety and rights in a legally binding agreement. That is why...experts dubbed it a 'major breakthrough' and 'game changer'..." (Khan \& Wichterich, 2015: 11-12). Media stories and NGO reports focused on this point, emphasizing 
the agreement as "legally binding" and "legally enforceable", and brands woefully cited its potential for "unlimited legal liability" (Clean Clothes Campaign, 2013b; Greenhouse, 2013). While the scope of responsibilities and governance structure of the Accord were undoubtedly among the unprecedented characteristics of the agreement, it was the legal liability mechanism that accounted for much of the fervor.

\section{LEGAL CONTEXT}

Ostensibly, the most extraordinary feature of the Accord is its legal clause that holds signatories liable in their home country courts for ensuring the remediation of factories in Bangladesh. Article 5 of the Accord - Dispute Resolution - states that, "Any dispute between the parties...shall first be presented to and decided by the [Steering Committee], which shall decide the dispute by majority vote of the SC...the decision of the SC may be appealed to a final and binding arbitration process. Any arbitration award shall be enforceable in a court of law of the domicile of the signatory against whom enforcement is sought..." (Accord on Fire and Building Safety in Bangladesh, 2013: 2). The text is both vague and focused on dispute settlement - as opposed to detailing the agreement's legal authority - which has given rise to its analysis by several legal scholars. The Brussels European Employees Relations Group was among them, which outlined the judicial role of the SC, acknowledged the ability for parties to appeal to a binding arbitration process, and clarified that the only role for domestic courts was to enforce the outcome of binding arbitration, rather than adjudicate on the dispute itself (Hayes et al., 2013). This point was further emphasized in a report on the topic by the Worker Rights Consortium which states that, "It is important to note in this regard that the Accord is, at base, simply a contract. In this sense, the risks assumed by signatory companies are no different than those to which these same firms willingly expose themselves in the normal course of business in countries around the world, which routinely involves their entering into legally-binding agreements - with suppliers, contractors, creditors, and landowners, to name a few" (Hensler \& Blasi, 2013). Even UNI Global - one of the Accord's labor signatories - sought to quell the fears of nervous American retailers by stating that they have given the brands "every assurance that this Accord does not expose them to any litigation in the U.S. courts, apart from the possible enforcement of an arbitration award, which is a seldom used but important assurance that arbitration awards will be respected. ... There is no right to third party litigation. There are no class actions, or punitive damages or fines made possible by this Accord" (quoted in Hayes et al., 2013: 13). Seemingly, perhaps, the heralded "legally binding" nature of the Accord agreement is not as reliant upon hard law as it implies. Indeed, since the inception of the Accord in 2013, there has not been one documented case of arbitration, let alone a court enforcement of an arbitration award. Ergo, we can conclude that the legal clause of the Accord is more illusion than reality.

\section{ILLUSION PROMOTES RESPONSIBILITY}

The Accord codified companies' accession to the veritable governors of safety in Bangladesh's RMG factories. Accordingly, this empirical study sought to determine if and how the legal provision within the Accord contributed to this shift. Methodologically, the study draws primarily upon 35 interviews with representatives from companies, NGOs and labor, and the Accord organization. The investigation sought to understand if and how the illusion created 
by the Accord's "legally binding" provision has contributed to business' growing responsibilities at the organizational (company), industry (fast fashion) or institutional (business) levels.

\section{Organizational}

\section{Prevented Joining the Accord}

It was the legally-binding nature that caused some companies to refuse to join the Accord in the first place. Many of the large U.S. brands cited the legal provision as infeasible within their legal system, so at the eleventh hour walked away from Accord negotiations and created their own initiative, the Alliance for Bangladesh Worker Safety ("the Alliance"), a business-led initiative that shared essentially the same goals but without the legal clause and other novel provisions. The General Counsel of one company noted her concern "...that there is unlimited liability for the companies that sign the Accord. And the unions were unwilling to limit that liability. [It would be irresponsible] to sign my company up to essentially potentially endless arbitration in a very expensive system with unlimited liability." Similar accounts were given by other Alliance members, and regardless of analyses and assurances that it did not equal unlimited liability, the legal illusion of the Accord prevented many of these companies from joining.

\section{Drive Compliance}

Members of the Accord also discussed how the legal clause impacted their membership in and views on the Accord more generally. Nearly all of the interviewed signatories of the Accord noted how "serious" it was because of its legal clause. As one company put it, "...if you have something that's legally binding, maybe companies will take it a little bit more seriously, or at least put more resources into it." Other signatories welcomed the provision for its ability to ensure compliance of all of the members, because otherwise there would be "a lot of freeriders," member companies who otherwise would join in name only. From this and similar responses, it was clear that signatories and NGOs took the legal clause quite earnestly, and therefore took steps to ensure that they complied with the provisions of the Accord.

\section{Changes Operations}

Given the Accord's ability to compel compliance, it is unsurprising that fulfilling responsibilities necessitated a change in business operations for signatories. Many brands noted changes that they had made to their sourcing or sustainability practices. One company commented on activities at a peer company, noting that "it has actually forced them to start working on sustainability, so it is actually pushing the agenda." Other companies reported on increases to staffing levels, responsibilities and scope to ensure compliance. The Accord - via its legal illusion - incited changing to members' business operations.

\section{Industry}

Creates New Rules and Parameters 
One of the primarily implications of the Accord was its redefinition of the scope of responsibilities expected of its members, and ergo, the industry as a whole. Yet, perhaps ironically, while signatories could articulate that they had a new role to play and responsibilities to meet, the vagueness of the Accord initially proved challenging, particularly due to its legal illusion. One company reported that "the format of the Accord was very new, so we had to try to grasp the implications it had for the company and the legal side of it," and another company shared its fear that, "If I go into arbitration right now, I would be scared as [explicative]." While initially unclear, companies acknowledged that collectively they had new responsibilities as businesses within the fast fashion industry, as well as a legal obligation to meet them.

\section{Alters Dynamics Between Actors}

The legal clause largely codified the shifting roles between actors, particularly from government to industry. One signatory reported that " the big change for us is to have a legally binding document that says we are taking over the responsibility of government," and when asked about tangible changes that the Accord had made, went on to say that the Accord "...is one of the first steps involved in taking the legal responsibility and trying to cooperate with governments." Other companies made similar comments about how the Accord changed working relationships with the government, trade unions and peer companies, all of which underscore the changing dynamics between actors within the industry.

\section{Changes Industry Business Model}

In addition to the primary task of inspecting and remediating factories, the Accord changed how western companies go about sourcing product from Bangladesh. Companies were required to maintain sourcing volumes at factories for at least two years, a practice at odds with the standard practice of continually shopping around for the best price. One company reported on its enlightenment of the new practice, "We're trying to keep long-term relations because it turns out we get better products. You have much better business. It's kind of obvious when you think about it." While business model changes are operationalized at the organizational level, the aggregate change to sourcing practices signifies an industry-level adaptation.

\section{Institutional}

\section{Evolving Norms and Expectations of Business}

As discussed previously, the scope of the Accord was unprecedented, and has established a new standard for RMG sourcing. Never before had private regulation so sweepingly reappropriate roles and responsibilities from government to business. As one respondent put it, "The Accord unified so many brands behind a common purpose, and is also legally binding." Another went on to reflect that the Accord had "definitely increased the awareness that there is no end to the responsibility that we have in sourcing countries." The Accord's legal illusion promoted the institutionalization of a new level of responsibility for business (Gilbert, Rasche, \& Waddock, 2011).

\section{Endorsement of Responsibility Shifts}


As importantly, the changes incited by the Accord and its legal illusion have not been limited to Accord members, but have been shaped and reinforced by outside actors. For instance, western governments not just supported but actually encouraged companies to join. The European Union is one such example, which issued a joint statement with the Bangladesh government and ILO stating their support for the Accord. "They welcome the fact that over 70 major fashion and retail brands sourcing RMG from Bangladesh have signed an Accord on Fire and Building Safety to coordinate their efforts to help improve safety in Bangladesh's factories which supply them. In this context, they encourage other companies, including SMEs, to join the Accord expeditiously within their respective capacities." Governmental endorsement further legitimized the institutional shift heightening the norms and expectations of responsible business (Gond, Kang, \& Moon, 2011).

\section{ILLUSORY LAW}

The legal illusion created by the Accord has been performative. Companies changed their actions, the media formulated their judgements, and activists and experts in the area have heralded it as a breakthrough. As discussed previously, analysis of the legal provision concluded both that disputes were unlikely to ever reach the courts, and even if they did, would be limited in scope to simply enforcing prior decisions. Herein we see a reversal of the age-old metaphor, that the Accord's disguise of soft law as hard law is simply a mere sheep in wolf's clothing.

With trade unions and other advocates calling for future initiatives to also include similar provisions of using hard law to enforce soft, it may be helpful to define the approach, proposed here as illusory law. Illusory law can be defined as hard or soft law that is stricter in appearance than function, thereby creating an illusion that incites greater compliance than would have otherwise been the case. Illusory law may appear in hard law when government creates a law where either or both compliance and/or enforcement is infeasible, or in soft law when penalties or enforcement are purported to be greater than is truly possible. Illusory law is evident in many hard laws; one such example is one of the provisions within the U.S. Dodd-Frank Act that requires companies to report on the origin of all conflict minerals within their supply chains. Global value chains of conflict minerals do not yet have the ability to be fully traceable, so companies have responded by reporting as far up the value chain that they can and have thus far not been sanctioned by the U.S. government for non-compliance. Illusory law is also burgeoning in soft law, as seen with the Accord. Illusory law itself is a spectrum; some illusory laws may be aspirational in nature, designed to spur progress in a particular area - as seen with the DoddFrank Act - and others may seek to ensure compliance - such as with the Accord. In either scenario, illusory law contributes to the pressure for business to take on greater responsibility for the public good.

The performativity of such an illusion turns the fabled "wolf in sheep's clothing" metaphor on its head; rather than a wolf disguising itself as a sheep to get close to the flock, the Accord is more of a sheep in wolf's clothing, with a hard and frightening costume over its much softer body.

\section{REFERENCES AVAILABLE FROM THE AUTHOR}

